\title{
The Possible Protective Role of Ginger Extract Versus Vitamin E Against Simvastatin-Induced Skeletal Myotoxicity in Adult Male Albino Rats: Histological, Physiological and Biochemical Study
}

\author{
Original \\ Article \\ Kawther M. Abdel Hamid ${ }^{1}$, Asmaa Fathi Abdel Mola ${ }^{1}$, FatmaY. Meligy ${ }^{1}$, \\ Eman S. H. Abd Allah ${ }^{2}$ \\ ${ }^{1}$ Histology and ${ }^{2}$ Medical Physiology Departments, Faculty of Medicine, Assiut University, \\ Assiut, Egypt
}

\begin{abstract}
Introduction: Statins are group of drugs used to reduce total and low density lipoprotein (LDL)-cholesterol level and to reduce the morbidity and mortality of cardiovascular diseases. Meanwhile, induced skeletal muscle- specific mitochondrial impairment, oxidative stress and myotoxicity are serious side effects . Vitamin E and ginger extract are well known potent antioxidants.

Aim: To study the possible protective effect of ginger extract versus vitamin E against simvastatin- induced skeletal muscle histological and the associated biophysiological changes.

Materials and Methods: Forty adult male albino rats were randomly divided into four equal groups (10 rats, each).; Group 1: was the control rats. Group 2: received $0.54 \mathrm{mg} / \mathrm{kg} /$ day simvastatin orally for 8 weeks. Group 3: received concomitant treatment of simvastatin and $30 \mathrm{mg} / \mathrm{kg}$ /day vitamin E orally for 8 weeks. Group 4 received concomitant treatment of simvastatin and $500 \mathrm{mg} / \mathrm{kg} /$ day ginger extract orally for 8 weeks. After sacrifice, specimens were taken from the belly of the quadriceps femoris muscles of all animal groups and processed for light and electron microscopy. Biochemical tests and statistical analysis were done.

Results: Group 2 showed focal areas of muscle fiber loss, mononuclear cellular infiltration and variable staining density. Ultra structurally, myofibrillar degeneration and accumulation of numerous giant infrequently damaged mitochondria were observed. The skeletal muscle fibers of animals from group 3 and group 4, both were markedly improved. Group 4 revealed obviously normal mitochondria.

Conclusion: Administration of simvastatin for 8 weeks induced histological, physiological and biochemical skeletal myotoxic effects. These effects were greatly ameliorated by concomitant administration vitamin E or ginger extract. Ginger extract was more effective.
\end{abstract}

Keywords: Ginger extract, mitochondrial biogenesis, myotoxicity, oxidative stress index, simvastatin, ultrastructure, vitamin $\mathrm{E}$

Revised: 30 August 2015, Accepted: 06 July 2017

Corresponding Author: Asmaa Fathi Abdel Mola, PhD, Department of Histology, Faculty of Medicine, Assiut University, Assiut, Egypt, Tel.: +20966568902355, E-mail: asmaanoorahmed@yahoo.com

ISSN: 1110-0559, 2017, Vol 40. , No. 2

\section{INTRODUCTION}

Statins are groups of 3-hydroxy-3- methylglutaryl coenzyme A (HMG-CoA) reductase inhibitors that reduce total and low density lipoprotein (LDL), cholesterol and reduce the morbidity and mortality of cardiovascular diseases ${ }^{[1]}$. Moreover, statins have other cholesterolindependent effects such as decreasing inflammation, improving endothelial function and enhancing the stability of atherosclerotic plaques ${ }^{[2]}$. When combined with antioxidant vitamins, statins have been shown to induce therapeutic angiogenesis in the management of diabetesassociated peripheral arterial disease ${ }^{[3]}$. In the last few years, the use of statins has been extended to the treatment of other disease including ventricular arrhythmias, idiopathic dilated cardiomyopathy, cancer, osteoporosis and diabetes ${ }^{[4]}$. Although statins are well tolerated, 17\%- of statin-treated patients suffer from myotoxicity ranging from muscular fatigability to strong myalgia and in the severest case rhabdomyolysis ${ }^{[2]}$. Risk factors for the development of a statin-induced myopathy include high dosages, increasing age, female sex, renal and hepatic insufficiency, diabetes mellitus and concomitant therapy with drugs such as fibrates, cyclosporine, macrolide antibiotics, warfarin and $\operatorname{digoxin}^{[5]}$. Statins decreased membrane cholesterol and thereby affecting membrane ionic channels and disrupting calcium handling ${ }^{[6,7]}$. Moreover, statins induced muscle-specific mitochondrial impairment and oxidative stress ${ }^{[2]}$.Vitamin E (tocopherol) is considered a major fat soluble antioxidant and is commonly used to combat the injury and oxidative stress associated with exercise as a nutritional antioxidant ${ }^{[8-10]}$. It also possesses powerful 
neuroprotective, anti-cancer, and cholesterol lowering properties $^{[11-13]}$.

Zingiber officinale Roscoe, commonly known as ginger, is one of the commonly used spices around the world ${ }^{[14]}$. Ginger is ranked one of the plants with highest antioxidant values ${ }^{[15,16]}$. Ginger contains active phenolic compounds that have antioxidant ${ }^{[17]}$, anti-cancer ${ }^{[18]}$. anti-inflammatory ${ }^{[19]}$ and antithrombotic properties ${ }^{[20]}$ and significantly reduces plasma cholesterol leve ${ }^{[3,21,22]}$. Up to our knowledge, the possible modulating effect of ginger or vitamin $E$ on statins associated skeletal myopathy has not been investigated yet.

\section{AIM OF THE WORK}

To evaluate the possible protective role of ginger extract versus vitamin $\mathrm{E}$ against simvastatin associated myotoxic histological and biophysiological effects in quadriceps femoris muscle in rats, aiming to get benefit from both the hypolipidemic and the muscular protective properties of either of them.

\section{MATERIALS AND METHODS}

\section{I- Chemicals:}

Simvastatin was obtained from Zocor tablets $20 \mathrm{mg}$ (Global Napi Pharmaceuticals- Egypt). Vitamin E capsules $(400 \mathrm{mg})$ were obtained from PHARCO pharmaceuticals. Pure ginger extract powder was purchased from Sigma Chemical Company.

\section{II- Animals:}

A total number of 40 adult male albino rats weighing (200 -250 gms) obtained and housed in clean capacious cages (up to 4 per cage). They were maintained on a natural 12:12-h light-dark cycle in an aerated room, temperature $\left(25 \pm 5^{\circ} \mathrm{C}\right)$, food (standard rat pellets) and water available ad libitum. The experimental protocol was approved by the Institutional Animal Research Committee of the Faculty of Medicine, Assiut University, Egypt, and carried out in line with the ethical considerations, recommended by Faculty of Medicine, Assiut University, Egypt.

\section{II-Experimental Groups:}

The rats were randomly divided into four groups, ten animals each as follows:

Group 1 (control group): was further subdivided into subgroup 1a received $0.5 \mathrm{ml} / \mathrm{kg}$ /day distilled water orally via intragastric tube for 8 weeks and subgroup $1 \mathrm{~b}$ received propylene glycol (the vehicle for simvastatin) orally using intragastric tube at a dose of $0.5 \mathrm{ml} / \mathrm{kg} / \mathrm{day}$ for 8 weeks.

Group 2 (simvastatin-treated group): treated with simvastatin (Zocor) dissolved in propylene glycol ( 0.54 $\mathrm{mg} / \mathrm{kg} /$ day) orally using intragastric tube for 8 weeks ${ }^{[23]}$.

Group 3 (combined simvastatin and vitamin E- treated group): received concomitant treatment of simvastatin as in group 2 and vitamin $\mathrm{E}$ at a dose of $30 \mathrm{mg} / \mathrm{kg} / \mathrm{day}$ orally using intragastric tube for 8 weeks ${ }^{[24]}$.

Group 4 (combined simvastatin and ginger-treated group): received concomitant treatment of simvastatin as in group 2 and ginger $(500 \mathrm{mg} / \mathrm{kg} /$ day) dissolved in distilled water via intragastric tube for 8 weeks ${ }^{[25]}$.

At the end of the experiment, all animals were sacrificed under general anesthesia. The belly of quadriceps femoris muscle was dissected away from tendon insertion of the right limb of each rat and was divided into small pieces. Specimens were fixed and processed for light and electron microscopy.

\section{(1) For Light microscopy}

Specimens were fixed in $10 \%$ neutral buffered formalin, dehydrated in ascending grades of alcohol, cleared then embedded in paraffin. Paraffin sections of $5 \mu \mathrm{m}$ thickness were cut and stained with hematoxylin and eosin $(\mathrm{H} \& \mathrm{E})$ for general histological structure, and phosphotungestic acid haematoxylin (PTAH) for skeletal muscle striations ${ }^{[26]}$.

\section{(2) For Electron microscopy}

Thin longitudinal muscle strips were cut and immersed in $2.5 \%$ glutaraldehyde buffered with $0.1 \mathrm{M}$ cacodylate $(\mathrm{pH} 7.2)$ for 2 hours. The specimens were thereafter washed three times with the same buffer and post fixed in $1 \%$ buffered osmium tetroxide for 2 hours then dehydrated in graded series of ethanol, infiltrated with epoxy resin mixture and embedded in epon-araldite mixture. Ultrathin sections were cut by LKB ultratome and stained with uranyl acetate and lead citrate ${ }^{[27]}$. The ultrastructural analysis was carried out with transmission electron microscope (Joel TEM CS 100) in the Electron Microscopic Unit, Assuit University, Egypt.

\section{(3) Biochemical tests}

Blood samples were taken from each rat via retro orbital vein before sacrifice. Blood samples were initially centrifuged at 3000 round per minute (rpm) for 15 minutes. The clear, non hemolysed supernatant sera were removed and kept at $-20^{\circ} \mathrm{C}$ until use for 
analysis. Serum creatine kinase (CK) concentration (IU/l) was determined using a spectrophotometric assay. Serum total antioxidant capacity (TAC) was measured calorimetrically using commercial kit (Bio-Diagnostics, Giza, Egypt ${ }^{[28]}$. Serum total peroxide (TP) was measured as described by Harma et $a l^{[29]}$. Oxidative stress index, an indicator for oxidative stress, was calculated as the percentage ratio of TP to TAC in $\mathrm{mM} / \mathrm{L}^{[29]}$.

\section{IV-Statistical analysis}

Data are presented as mean \pm standard error (SEM). The data were analyzed using one-way ANOVA to compare various groups with each other. Differences were considered statistically significant if $p<0.05$.

\section{RESULTS}

\section{H\&E-stained sections:}

In longitudinal sections, skeletal muscle fibers of control animals $(\mathrm{G} 1 \mathrm{a}, \mathrm{b})$ appeared elongated, cylindrical and ran in parallel. They were separated from each other by fine loose connective tissue (endomysium). Muscle fibers had acidophilic cytoplasm (sarcoplasm), multiple peripheral cigar-shaped nuclei and showed well-defined transverse striations (Fig. 1).

Skeletal muscle fibers of simvastatin treated group (G2) showed variable staining density of their sarcoplasm, dense nuclei and focal areas of loss of fiber continuity with endomysial and sarcoplasmic mononuclear cellular infiltration (Fig. 2).

Muscle fibers of both combined simvastatin and vitamin E treated animals (G3) and combined simvastatin and ginger treated animals (G4) showed obvious improvement compared with group 2 (Figs. 3 and 4).

\section{Phosphotungestic acid haematoxylin (PTAH)- stained sections:}

In control group (G1a, b), skeletal muscle fibers showed well-distinct regular transverse striations (Fig. 5).

Skeletal muscle fibers of simvastatin treated group (G2) showed variability of staining affinity with obvious and frequent loss of transverse striations. Focal areas of muscle fiber loss were also noticed (Fig. 6).

In combined simvastatin and vitamin E treated group (G3), the muscle fibers showed variability of staining affinity of some fibers with infrequent focal areas of muscle fiber loss (Fig. 7).

Skeletal muscle fibers of combined simvastatin and ginger treated group (G4) showed obvious improvement compared with group (G2) and(G3) (Fig. 8).

\section{Electron microscopic examination:}

Examination of ultrathin sections of skeletal muscle fibers of control group (G1a, b) showed oval cigar shaped nuclei under the sarcolemma having heterochromatin clumps distributed along the inner surface of the nuclear envelope, mitochondria with intact cristae under sarcolemma and around the nucleus and regularly parallel arranged myofibrils occupying the sarcoplasm. Myofibrils showed regular arrangement of alternating light (I) and dark (A) bands. Pale narrow regions, $\mathrm{H}$ bands, could be seen transecting A bands. Dark M lines were observed within $\mathrm{H}$ bands. Z-lines were seen bisecting the light band. Repetitive sarcomeres were defined between each two successive $\mathrm{Z}$ lines. Vesicles of sarcoplasmic reticulum were found among myofibrils (Figs. 9a, b).

Skeletal muscle fibers of simvastatin treated group (G2) showed irregular nuclei, focal areas of myofibrillar loss with disruption of Z-line and dilatation of the sarcoplasmic reticulum cisternae. There was obvious accumulation of extraordinary number of giant mitochondria sometimes with destructed cristae under the sarcolemma, among myofibrils and around nuclei. Mast cells were sometimes observed in the endomysial mononuclear cellular infiltrate (Figs. 10a, b, and c).

In simvastatin and vitamin E treated group (G3), skeletal muscle fibers had apparently normal parallel myofibrils, with regular arrangement of alternating light (I) and dark (A) bands. Most mitochondria had more or less normal appearance while still nuclei had irregular outlines sometimes with dilated perinuclear cisternae. Infrequent foci of degeneration were noticed. (Figs. 11a, and $b$ ).

The examined ultrathin sections of skeletal muscle fibers of combined simvastatin and ginger treated group (G4) showed numerous mitochondria with intact cristae clearly visible under sarcolemma, around the nuclei and in parallel rows among myofibrils. Myofibrils and sarcoplasmic reticulum appeared more or less similar to the control group. Nuclei were folded and euchromatic (Figs.12a, and b).

\section{Biochemical and physiological results:}

Muscle weight to body weight ratio was significantly reduced in simvastatin-treated group (Histogram 1). Concomitant treatment of vitamin $\mathrm{E}$ or ginger with simvastatin restored muscle weight to body weight ratio.

Histogram 2 showed that simvastatin significantly increased serum $\mathrm{CK}$ concentration $(P<0.001)$. In 
contrast, concomitant treatment of simvastatin with vitamin $\mathrm{E}$ and ginger significantly decreased serum CK concentrations $(P<0.001)$. The effect of ginger was significantly higher than the effect of vitamin $E$ in reducing serum $\mathrm{CK}$.

Serum TAC was significantly decreased in simvastatin-treated group as compared to control group. Concomitant treatment of vitamin E or ginger with simvastatin significantly increased serum TAC as compared to simvastatin-treated group. In contrast, serum TP was significantly increased in simvastatintreated group as compared to control group. Concomitant treatment of vitamin $\mathrm{E}$ or ginger with simvastatin significantly decreased serum $\mathrm{TP}$ as compared to simvastatin-treated group. In addition, oxidative stress index was significantly increased in simvastatin-treated group as compared to control. Concomitant treatment of vitamin $\mathrm{E}$ or ginger significantly decreased oxidative stress index as compared to simvastatin-treated group. The effect of ginger was significantly higher in reducing oxidative stress than that of vitamin E (Table 1).

Table 1: Serum total antioxidant capacity, total peroxide and oxidative stress index in all the studied groups

\begin{tabular}{|c|c|c|c|c|}
\hline & Control & Simvastatin & Simvastatin + vit. E & Simvastatin + ginger \\
\hline \multicolumn{5}{|l|}{$\mathrm{TAC} \mathrm{mM} / \mathrm{L}$} \\
\hline & $1.08 \pm 0.016$ & $0.63 \pm 0.0057 *$ & $0.76 \pm 0.003 * \#$ & $0.89 \pm 0.007 * \# \dagger$ \\
\hline $\mathrm{TP} \mathrm{mM} / \mathrm{L}$ & $0.106 \pm 0.0005$ & $0.119 \pm 0.0004 *$ & $0.116 \pm 0.0003^{* \#}$ & $0.115 \pm 0.0004 * \#$ \\
\hline \multicolumn{5}{|l|}{ OSI } \\
\hline & $10.53 \pm 0.119$ & $18.96 \pm 0.192 *$ & $15.21 \pm 0.08 * \#$ & $12.95 \pm 0.123 * \# \dagger$ \\
\hline
\end{tabular}

Data are presented as means \pm SEM ( $\mathrm{n}=10$ in each group).

$* P<0.05$ when compared with control group

$\# P<0.05$ when compared with simvastatin-treated group

$\uparrow P<0.05$ when comparing simvastatin + vitamin E-treated group versus simvastatin + ginger-treated group

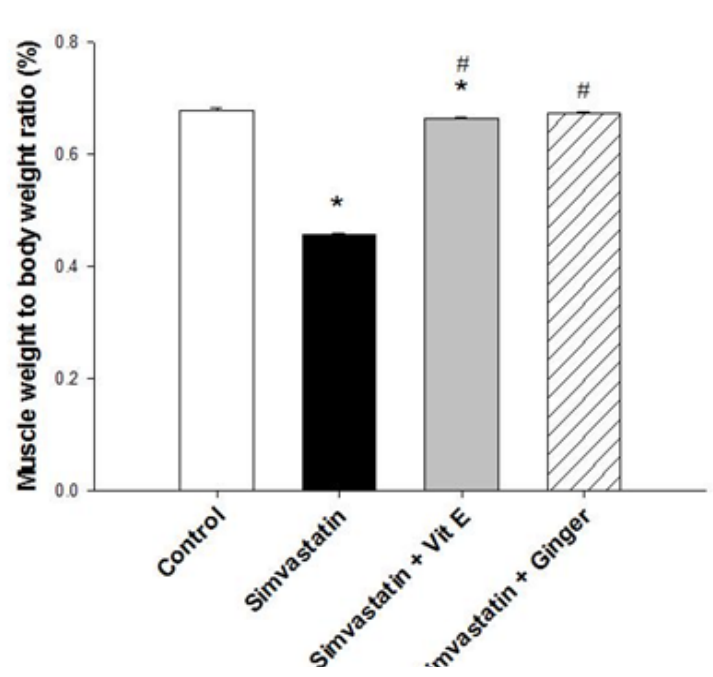

Histogram 1: Muscle weight to body weight ratio. Data are presented as mean \pm SEM. $* P<0.05$ when compared with control, \# $P<0.05$ when compared with simvastatin-treated group.

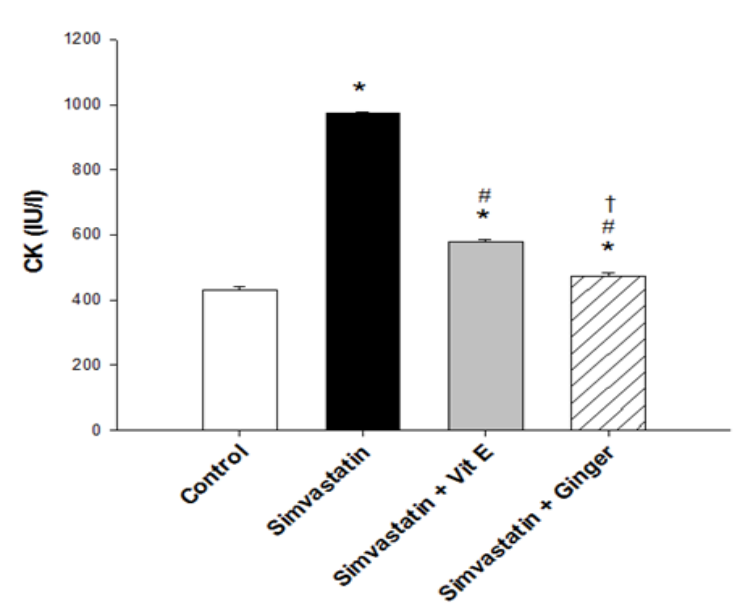

Histogram 2: Serum creatine kinase (CK) concentrations in control, simvastatin, simvastatin + Vitamin $\mathrm{E}$ and simvastatin + ginger treated animals. Data are presented as mean \pm SEM. $P<0.001$ when compared with control, $\# P<0.001$ when compared with simvastatin-treated group and $\dagger P<0.01$ when comparing simvastatin + vitamin E- versus simvastatin + ginger-treated groups. 

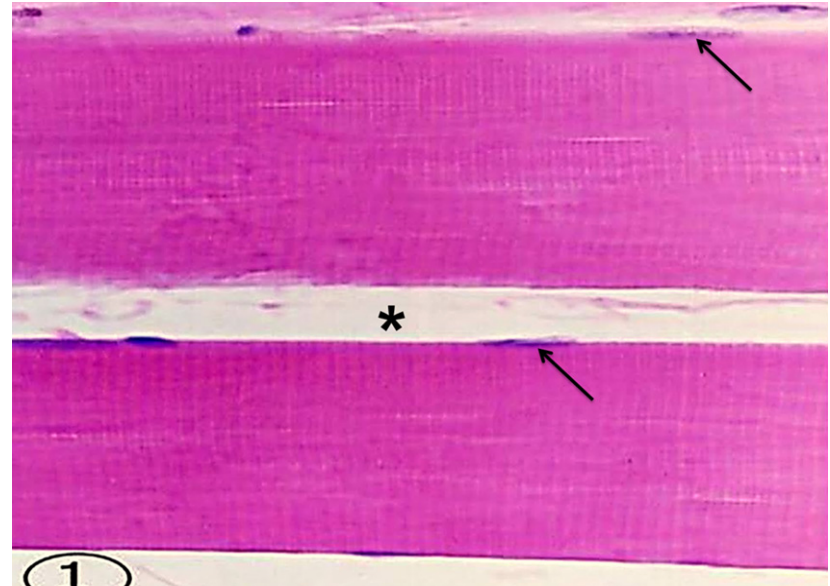

(1)

Fig. 1: A photomicrograph of a longitudinal section of quadriceps femoris muscle of the control group (Group 1a,b) showing parallel muscle fibers separated by endomysium $(*)$. They have acidophilic cytoplasm with distinct transverse striations and peripherally located cigar shaped nuclei $(\rightarrow) . \quad(H \& E x 400)$.

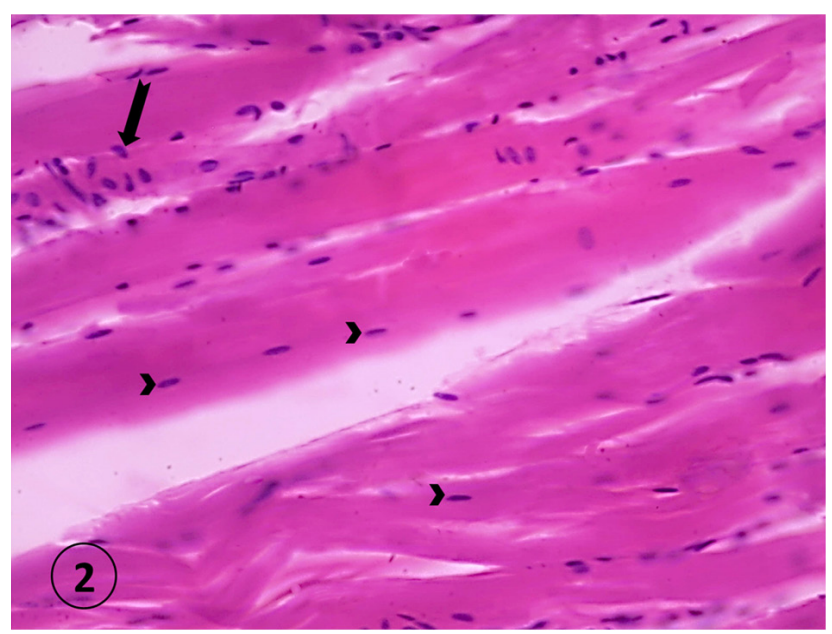

Fig. 2: A photomicrograph of a longitudinal section of quadriceps femoris muscle of simvastatin treated group (Group 2) showing dense nuclei (arrow heads),variable staining affinity of the sarcoplasm with ill-defined cross striations and localized mononuclear cell infiltration $(\overrightarrow{\vec{z}})$ $(H \& E x 400)$.

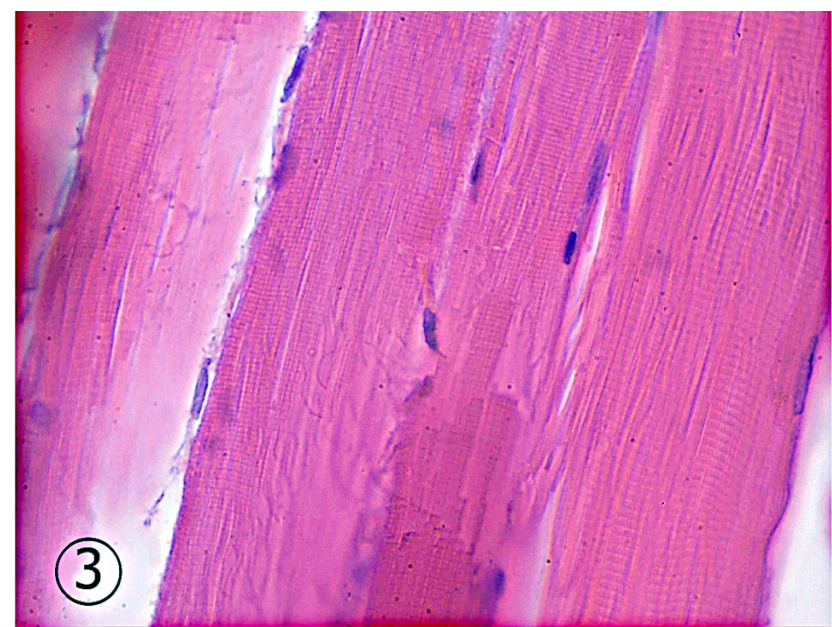

Fig. 3: A photomicrograph of a longitudinal section of quadriceps femoris muscle of combined simvastatin and vitamin $\mathrm{E}$ treated group (Group 3) showing cylindrical muscle fibers arranged in parallel more or less similar to the control group.

$(\mathrm{H} \& \mathrm{E} x 400)$.

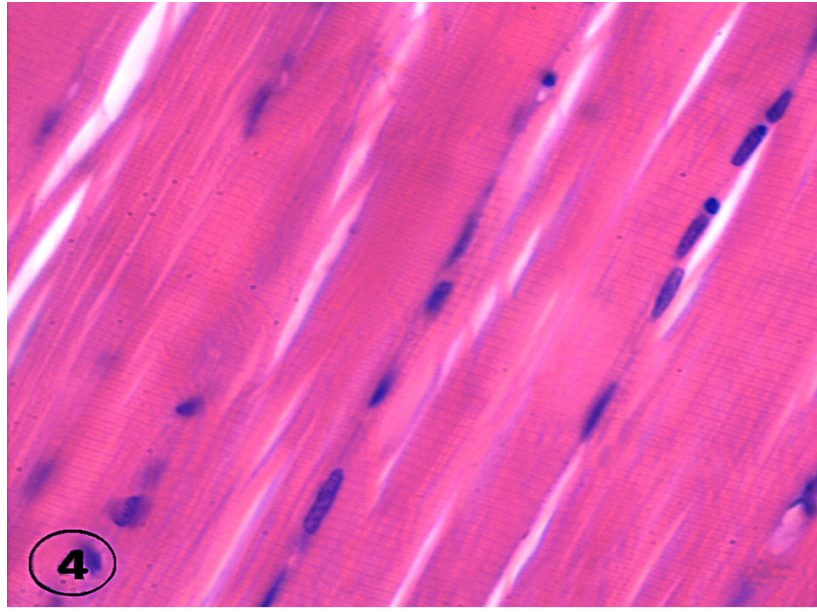

Fig. 4: A photomicrograph of a longitudinal section of quadriceps femoris muscle of combined simvastatin and ginger treated group (Group 4) showing muscle fibers appeared more or less similar to the control group.

(H\&E x400)

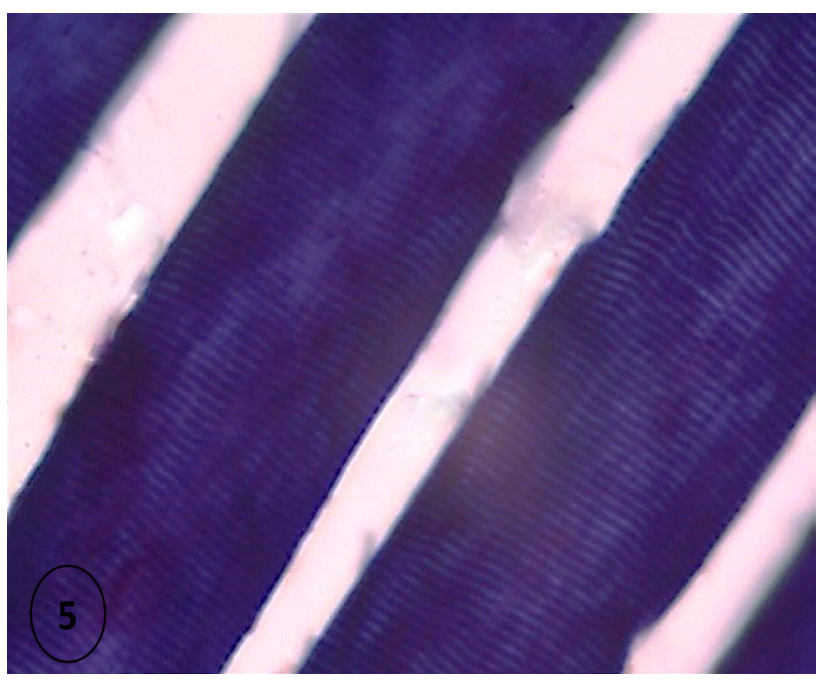

Fig. 5: A photomicrograph of a longitudinal section of quadriceps femoris muscle of the control group (Group 1a,b) showing well distinct transverse striations in parallel myofibers

(PTH x400).

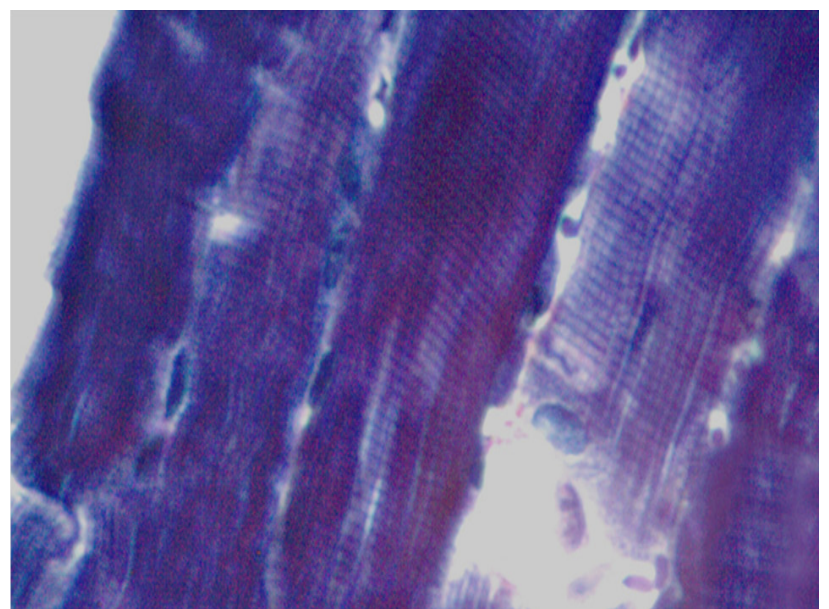

Fig. 6: A photomicrograph of a longitudinal section of quadriceps femoris muscle of simvastatin treated group (Group 2) showing decreased or lost cross striations, variability in staining density of fibers with focal area of muscle fibers loss $(\rightarrow)$ (PTH x400) 

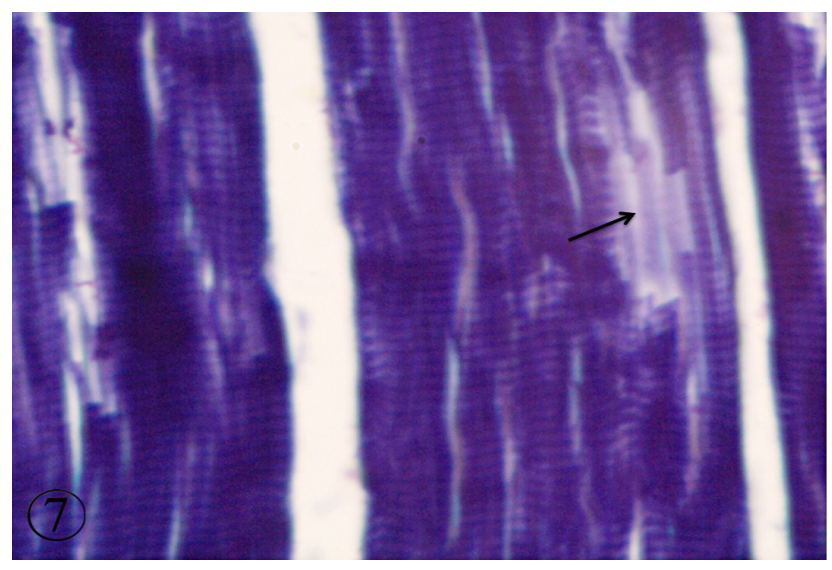

Fig. 7: A photomicrograph of a longitudinal section of quadriceps femoris muscle of combined simvastatin and vitamin $\mathrm{E}$ treated group (Group 3 ) showing variability in staining with variable loss of some muscle fibers $(\rightarrow)$

(PTH x400).

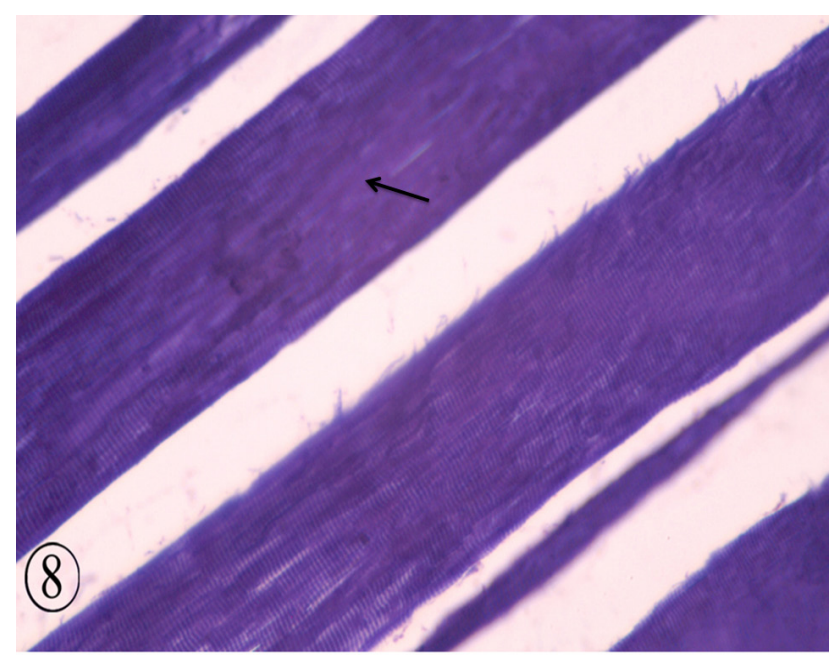

Fig. 8: A photomicrograph of a longitudinal section of quadriceps femoris muscle of combined simvastatin and ginger treated group (Group 4) showing more or less normal fibers with areas of illdistinct striations of some fibers $(\rightarrow)$ (PTH x400).

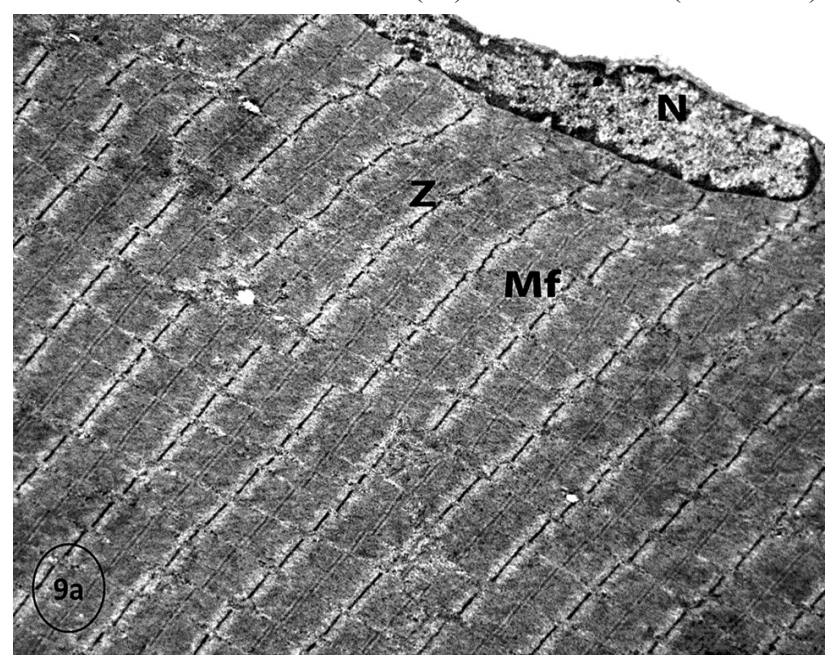

Fig. 9a: An electron micrograph of a longitudinal section of quadriceps femoris muscle of the control group (Group 1a,b) showing parallel myofibrils (Mf) with light and dark bands. Z lines $(\mathrm{Z})$ bisect light bands. The nucleus $(\mathrm{N})$ is oval elongated and lies just beneath the sarcolemma

(X 4800).

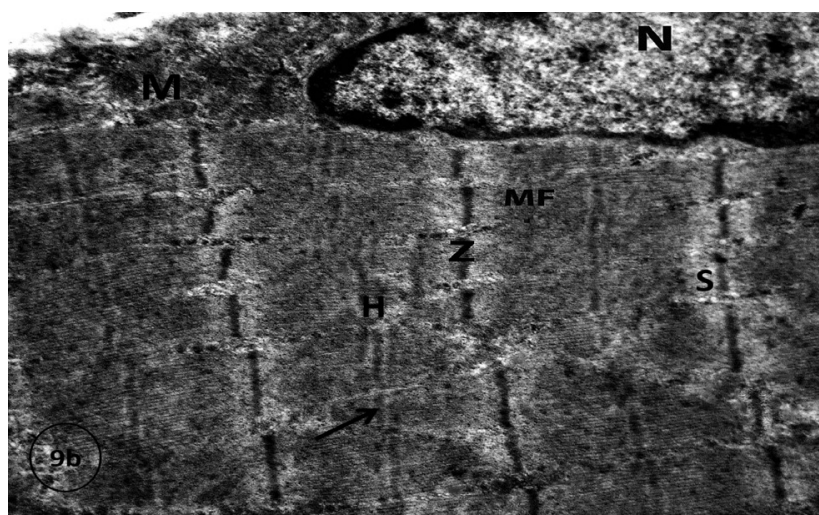

Fig. 9b: An electron micrograph of a longitudinal section of quadriceps femoris muscle of the control group (Group 1a,b) showing parallel myofibrils (Mf) with light and dark bands. Sarcomeres are seen between each two successive $Z$ lines $(Z)$. Some elongated mitochondria (M) appears under sarcolemma near the nucleus $(\mathrm{N})$. Cisternae of sarcoplasmic reticulum $(\mathrm{S}), \mathrm{H}$ band $(\mathrm{H})$ and $\mathrm{M}$ line are observed $(\rightarrow)$

(X 14000).

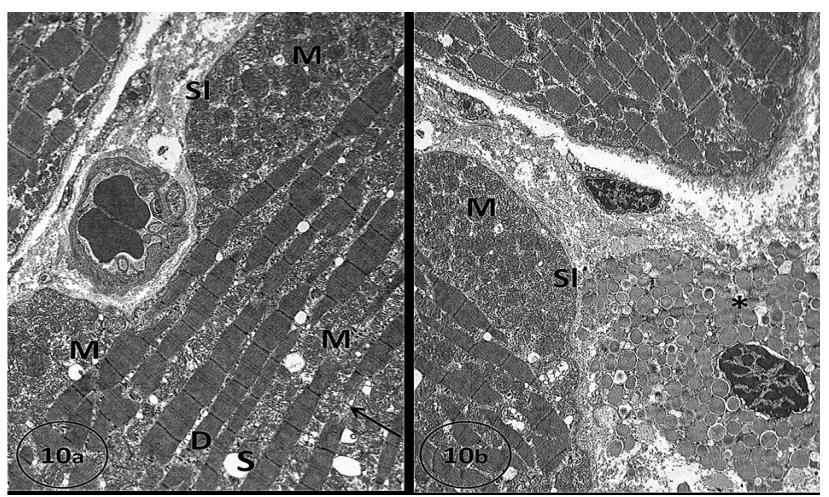

Fig. 10a-b: An electron micrograph of a longitudinal section of quadriceps femoris muscle of simvastatin treated group (Group 2) showing accumulation of large number of giant mitochondria (M) with destructed cristae beneath sarcolemma (Sl) and among the parallel myofibrils. Foci of degeneration of myofibrils (D), disruption of $\mathrm{Z}$ line $(\rightarrow)$ and dilated sarcoplasmic reticulum cisternae (S) are noticed Notice a mast cell is present in the endomysial cellular infiltrate $\left.{ }^{*}\right)$ (Fig. 10b) (X 4800).

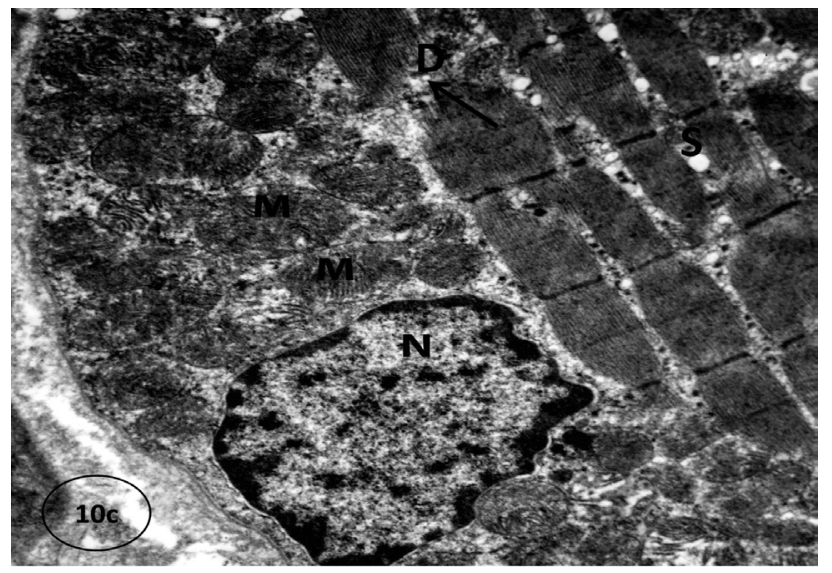

Fig. 10c: An electron micrograph of a longitudinal section of quadriceps femoris muscle of simvastatin treated group (Group 2) showing foci of degeneration of myofibrils (D) and disruption of $\mathrm{Z}$ line $(\rightarrow)$.The nucleus $(\mathrm{N})$ has irregular outline with accumulation of large number of giant mitochondria (M). Notice destructed cristae of some mitochondria and dilated sarcoplasmic reticulum cisternae (S)

(X 10000) 


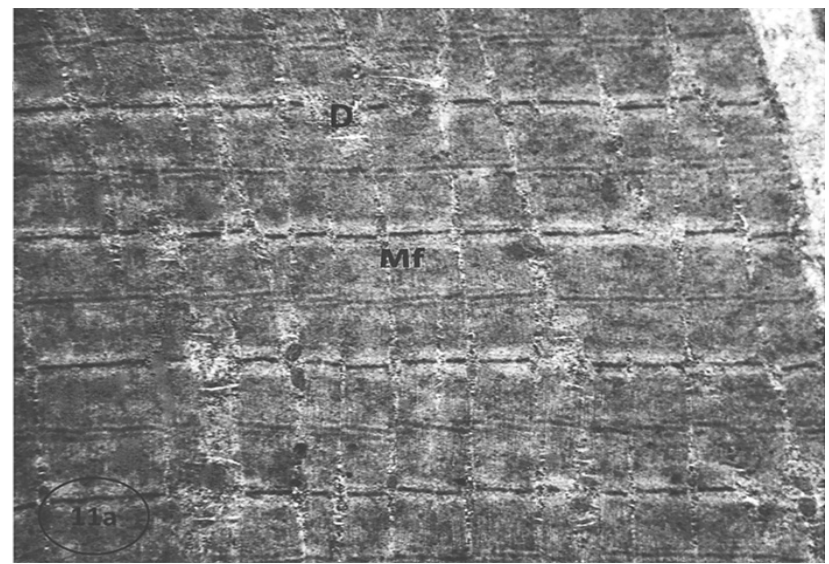

Fig. 11a: An electron micrograph of a longitudinal section of quadriceps femoris muscle of combined simvastatin and vitamin E treated group (Group 3) showing parallel arrangement of myofibrils (Mf) of more or less normal appearance Still few foci of degeneration (D) are noticed

(X4800).

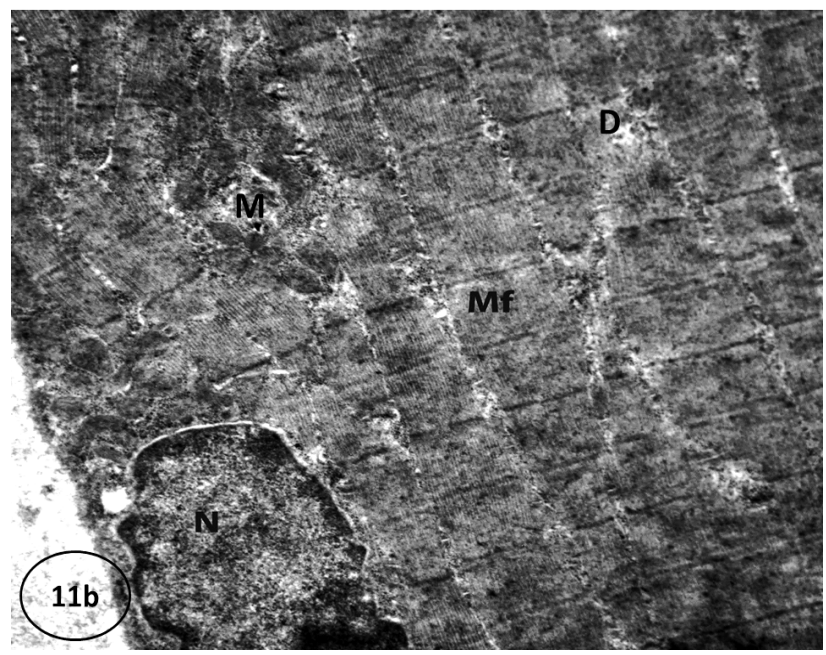

Fig. 11b: An electron micrograph of a longitudinal section of quadriceps femoris muscle of combined simvastatin and vitamin E treated group of (Group 3) showing normal appearance of most myofibrils (Mf). Some intact mitochondria (M) are observed. Nucleus (N) has irregular outline and dilated perinuclear cisternae. Notice; few foci of degeneration (D) are encountered

(X10000).

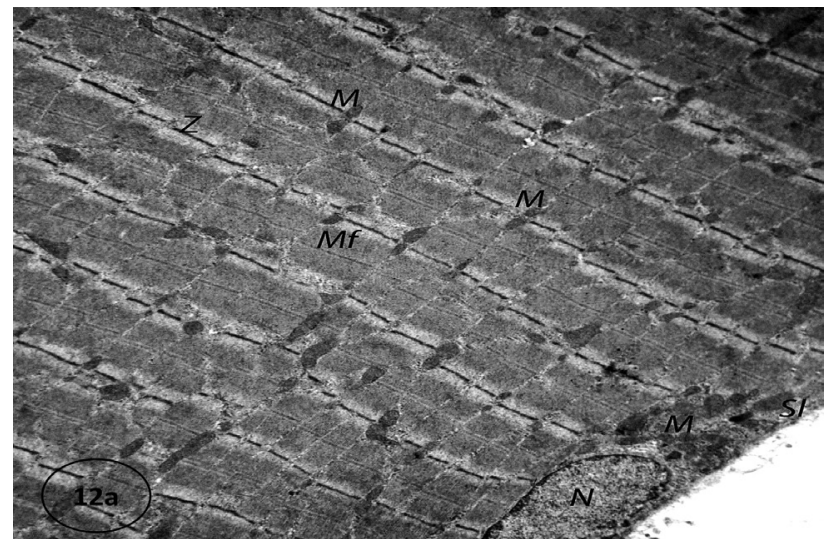

Fig. 12a: An electron micrograph of a longitudinal section of quadriceps femoris muscle of combined simvastatin and ginger treated group (Group 4) showing normal myofibrillar (Mf) aspect with accumulation of mitochondria (M) under sarcolemma (S1) and in pairs around $\mathrm{Z}$ lines

(X4800).

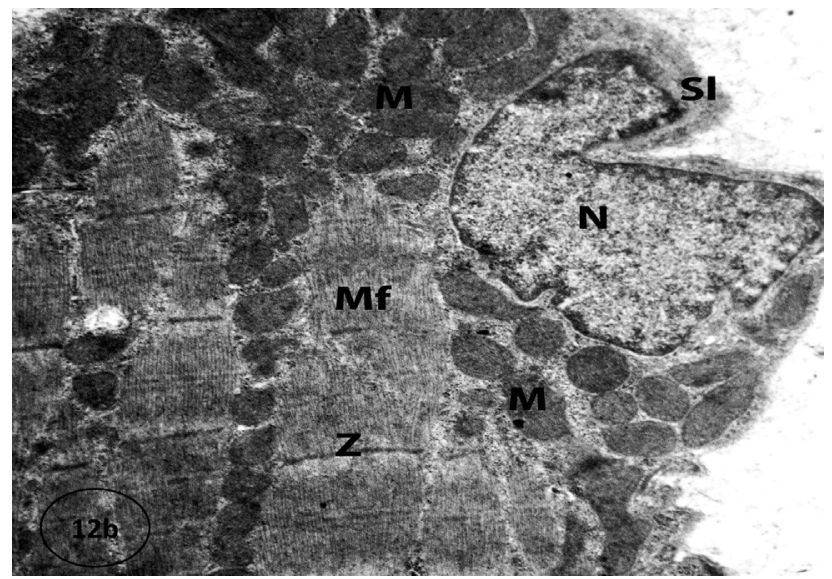

Fig. 12b: An electron micrograph of a longitudinal section of quadriceps femoris muscle of combined simvastatin and ginger treated group (Group 4) showing folded nucleus (N) lies just beneath the sarcolemma $(\mathrm{Sl})$ and accumulation of giant mitochondria $(\mathrm{M})$ of more or less normal appearance under the sarcolemma and among myofibrils (Mf)

( X 10000)

\section{DISCUSSION}

In the present work, treatment of adult male albino rats with simvastatin for 8 weeks led to obvious changes in the quadriceps femoris muscle fibers of adult albino rats.

The muscle fibers showed focal areas of cellular infiltration, focal areas of loss of continuity of the muscle fibers, loss of striations of the affected fibers. Besides, they showed variable staining densities with (H \& E) indicating cytoplasmic protein denaturation and an associating local inflammatory reaction. The histological and physiological changes induced by simvastatin might be of multifactorial etiology. Previous researches ${ }^{[30,31]}$ reported mitochondrial impairment and alteration of $\mathrm{Ca} 2+$ homeostasis specifically in skeletal muscle due to preferential uptake of statins by monocarboxylate transporter (MCT4). In addition, statininduced skeletal myopathy might be due to depletion of the isoprenoid pool by statins (HMG-CoA reductase inhibitors) with subsequent generalized insufficient protein modification inducing myopathy ${ }^{[32]}$. The histopathological adverse effects induced by statin in rat quadriceps femoris muscle fibers observed in the present work reinforce previous reports ${ }^{[33-35]}$. At the ultrastructure level, the focal areas of degenerated myofibrils showed disruption of Z-lines, dilated SER cisternae, together with numerous, subsarcolemmal and perinuclear, giant mitochondria, sometimes with destructed cristae. Giant mitochondria might arise by fusion of the mitochondria to be spared from degradation and to sustain ATP production during apoptosis induced by reactive oxygen species ${ }^{[36,37]}$. The fused giant mitochondria may be also one of the cellular defense or compensatory mechanisms to protect the cells from mitochondrial dysfunction by complementation of DNA products in fused mitochondria when these cells are exposed to toxic compounds ${ }^{[35-39]}$. 
In the present study, the characteristic presence of abnormal, subsarcolemmal and perinuclear, zonal accumulation of numerous, giant mitochondria, sometimes with destructed cristae is consistent with that of the ragged red fibers indicative of mitochondrial myopathies previously described by many authors ${ }^{[40,41]}$. In the mitochondrial myopathies, segmental distributions of mtDNA mutations can occur along the length of the muscle fiber ${ }^{[42]}$, concurrent with a corresponding upregulation of mitochondrial copy number in the mutant areas, presumably as a compensatory response to the mtDNA defect ${ }^{[43]}$. A strong link has been made between the presence of mtDNA mutations in skeletal muscle and the decrease in oxidative phosphorylation function ${ }^{[22]}$.

Up to our knowledge, this research might be the first histological one to raise the possibility that statin- induced skeletal muscle toxicity might be of the mitochondrial myopathic origin. This suggestion is well- supported by the previous report that a statin exhibited decreased skeletal muscle gene expression for oxidative phosphorylationrelated, and mitochondrial ribosomal protein genes in symptomatic subjects relative to asymptomatic subjects and that mitochondrial gene expression was also different at baseline before statin treatment between subjects who had and had not previously tolerated statin therapy. On the same line, the presence of biochemical and/or genetic abnormalities of proteins or genes that are involved in skeletal muscle-energy metabolism reported in more than $50 \%$ of statin-treated patients ${ }^{[44]}$.

In the present study, concomitant administration of simvastatin \&vitamin E greatly ameliorated the statinassociated myofibrillar ultrastructural changes. This might be attributed to vitamin $\mathrm{E}$ effect as a potent chain- breaking antioxidant and stabilizer of membrane structure, by scavenging free radicals that may harm membrane lipids, interacting with phospholipids and increasing the orderliness of membrane lipid packing ${ }^{[45-47]}$. So, it contributes to integrity of the sarcolemma. Moreover, vitamin E can inhibit protein kinase C, 5-lipoxygenase \& phospholipase A2 while activate protein phosphatase $2 \mathrm{~A} \&$ diacylglycerol kinase ${ }^{[48]}$ thus alleviating the statin - induced inflammatory reaction. A like vitamin $\mathrm{E}$ administration improved statin-induced muscular symptoms during exercise as ache and cramp like symptoms as well as muscle weakness that were the major group of adverse side-effects among statin users even in the absence of elevated creatine kinase $(\mathrm{CK})^{[49]}$.

In our study, the myofibrils and sarcoplasmic reticulum cisternae of simvastatin-\& ginger-treated animal group appeared more or less similar to the control group. Ginger could inhibit the toxic effects of simvastatin on nitric oxide production in activated macrophages. Nitric oxide activates the pro-inflammatory marker (COX-2) \& the proapoptotic marker (caspase 3). In addition, ginger inhibits release of cytokines that play an important role in initiating the inflammatory response to cell damage ${ }^{[50-52]}$.
In the current work, quadriceps femoris muscle fibers of simvastatin-\& ginger-treated animals showed subsarcolemmal, perinuclear and intermyofibrillar numerous, apparently normal mitochondria. A similar observation has been reported in the mitochondrial myopathic mice on oral supplementation with nicotinamide riboside, with an increase in mitochondrial mass, mtDNA, and respiratory chain protein amounts, indicating active oxidative metabolism that efficiently prevented development and progression of mitochondrial myopathy in mice ${ }^{[41]}$.

Subsequently, these findings raise the possibility that concomitant ginger treatment with simvastatin resulted in a remarkable induction of mitochondrial replication (biogenesis) consequently corrected oxidative metabolism and prevented, to a great extent, the development of toxic changes induced by simvastatin at the ultrastructure level. This possibility is supported by the advanced report that (S)-[6]-gingerol treatment significantly increased Peroxisome Proliferator-Activated Receptor- $\gamma$ Coactivator- $1 \alpha$ (PGC-1 $\alpha)$ mRNA expression within 5 hours in L6 myotubes and markedly increased mitochondrial content detected at a later time ${ }^{[53]}$. PGC-1 $\alpha$ is considered a key "master regulator" of mitochondrial biogenesis (replication) in tissues active in oxidative metabolism as the liver and the skeletal muscles ${ }^{[54]}$.

The protective effect of either vitamin $\mathrm{E}$ or ginger extract against simvastatin-associated myotoxicity is consistent with a previous research whereas concurrent ginger extract or vitamin $\mathrm{E}$ treatment with atorvastatin significantly attenuated the extent and severity of the histological features of liver damage induced by atorvastatin alone. A more significant reduction of oxidative stress marker was observed with ginger ${ }^{[55]}$.

Although, the histological and biophysiological changes-induced by simvastatin might be of multifactorial origin, the oxidative stress effect has been greatly suggested ${ }^{[56]}$. This suggestion is reinforced by our physiological findings that showed decreased serum total antioxidant capacity (TAC), increased serum (CK), serum total peroxide (TP) and increased oxidative stress index (OXI) in simvastatin- treated animal group as compared to control group. Oxidative stress caused by toxic molecules may play a critical role in subcellular remodeling and abnormalities of calcium handling. These changes likely resulted from accumulation of toxic molecules such as long-chain acylcarnitines, free radicals, and abnormal membrane lipid content ${ }^{[57]}$.

In our study, concomitant vitamin $\mathrm{E}$ or ginger extract administration with simvastatin significantly increased serum TAC, significantly decreased oxidative stress index (OSI), decreased serum TP as compared to simvastatintreated. However, the effect of ginger was significantly higher than that of vitamin $\mathrm{E}$ in reducing oxidative 
stress index( O S I) and in reducing serum CK. Ginger extract exhibited inhibitory effect on xanthine oxidase responsible for generation of reactive oxygen species, such as superoxide anion ${ }^{[58]}$, inhibits nitric oxide (NO) synthesis in activated macrophages and prevents oxidation and nitration reactions induced by peroxynitrite, a strong reactive nitrogen species ${ }^{[50]}$, has potent anti-inflammatory properties both in vitro and in vivo ${ }^{[51]}$ and possess a calcium antagonizing effect ${ }^{[59]}$. Meanwhile, it might induce active oxidative metabolism that efficiently prevented development and progression of mitochondrial myopathy as suggested in our ultrastructure observation.

In the present work, the muscle weight to body weight ratio was significantly reduced in simvastatin- treated animals. This weight loss might result from damage of the muscle fibers with subsequent protein degradation, denaturation and loss and/or the use of the stored fat in the muscle as an energy source. Spectroscopic findings reported protein denaturation and showed a decrease in protein, glycogen, nucleic acid, lipid content and an increase in lipid order and lipid dynamics in the simvastatin-treated muscle ${ }^{[60]}$. The decrease in the protein content of the muscle might reflect a situation of self-break down of the muscle protein (degradation) so as, to use the amino acids as an energy source because of the statin-induced decrease of the serum levels of lipids and fatty acids. This point of view is supported by the rise in serum CK observed in the present study and the previously reported rise in total serum CK and myoglobin content together with body weight loss of simvastatin-treated rats $^{[35]}$.

The protective role of vitamin $\mathrm{E}$ and ginger extract could be related-in part- to their antioxidant properties. Ginger extract appeared more protective, most probably, through induction of mitochondrial replication. Further investigations on the molecular mechanism of simvastatininduced skeletal muscle damage and whether vitamin $\mathrm{E}$ or ginger extract can fully combat this adverse side effect aiming to get benefit from both the hypolipidemic and the muscular protective properties of either of them are highly recommended.

\section{CONCLUSION}

Simvastatin administration for 8 weeks induced obvious histological, physiological and biochemical myotoxic effects in the quadriceps femoris muscle of adult male rats. These effects were obviously improved on concomitant administration of either vitamin $\mathrm{E}$ or ginger extract with simvastatin.

\section{CONFLICT OF INTEREST}

There are no conflicts of interest.

\section{REFERENCES}

1. Grundy SM. HMG-CoA reductase inhibitors for treatment of hypercholesterolemia. N Engl J Med
(1988); 319: 24 -33.

2. Sirvent $\mathbf{P}$, Mercier $\mathbf{J}$ and Lacampagne A. New insights into mechanisms of statin-associated myotoxicity. Curr Op in Pharmacol (2008); 8: $333-338$.

3. El-Azab MF, Hazem RM and Moustafa YM. Role of simvastatin and/or antioxidant vitamins in therapeutic angiogenesis in experimental diabetic hindlimb ischemia: effects on capillary density, angiogenesis markers, and oxidative stress. Eur J Pharmacol (2012); 690: 31 -41.

4. Dirks AJ and Jones KM. Statin-induced apoptosis and skeletal myopathy. Am J Physiol Cell Physiol (2006); 291: C1208-C1212.

5. Westwood FR, Bigley A, Randall K, Marsden AM and Scott RC. Statin-induced muscle necrosis in the rat: distribution, development, and fibre selectivity. Toxicol Pathol (2005); 33: 246- 257.

6. Galtier F, Mura T, Raynaud de ME, Chevassus H, Farret A, Gagnol JP, Costa F, Dupuy A, Petit P, Cristol JP, Mercier J, and Lacampagne A. Effect of a high dose of simvastatin on muscle mitochondrial metabolism and calcium signaling in healthy volunteers. Toxicol Appl Pharmacol (2012); 263: 281- 286.

7. Simsek ON, Bal IB, Sara Y, Onur R, and Severcan F. Structural and functional characterization of simvastatin-induced myotoxicity in different skeletal muscles. Biochim Biophys Acta (2014); 1840: $406-415$.

8. Sacheck JM and Blumberg JB. Role of vitamin E and oxidative stress in exercise. Nutrition (2001); 17: 809- 814 .

9. Jackson MJ, Khassaf M, Vasilaki A, McArdle $\mathrm{F}$, and McArdle A. Vitamin E and the oxidative stress of exercise. Ann N Y Acad Sci (2004); 1031: $158-168$.

10. Cordero Z, Drogan D, Weikert C, and Boeing H. Vitamin $\mathrm{E}$ and risk of cardiovascular diseases: a review of epidemiologic and clinical trial studies. Crit Rev Food Sci Nutr (2010); 50: 420- 440.

11. Qureshi AA, Qureshi N, Wright JJ, Shen Z, Kramer G, Gapor A, Chong YH, DeWitt G, Ong A, and Peterson DM. Lowering of serum cholesterol in hypercholesterolemic humans by tocotrienols (palmvitee). Am J Clin Nutr (1991); 53: 1021S-1026S.

12. Qureshi AA, Sami SA, Salser WA, and Khan FA. 
Dose-dependent suppression of serum cholesterol by tocotrienol-rich fraction (TRF25) of rice bran in hypercholesterolemic humans. Atherosclerosis (2002); 161: 199 -207.

13. Yu SG, Thomas AM, Gapor A, Tan B, Qureshi N, and Qureshi AA. Dose-response impact of various tocotrienols on serum lipid parameters in 5-weekold female chickens. Lipids (2006); 41: 453- 461.

14. Ajith TA, Nivitha V, and Usha S. Zingiber officinale Roscoe alone and in combination with alpha-tocopherol protect the kidney against cisplatin-induced acute renal failure. Food Chem Toxicol (2007); 45: 921- 927.

15. Ahmed RS, Seth V, and Banerjee BD. Influence of dietary ginger (Zingiber officinales Rosc) on antioxidant defense system in rat: comparison with ascorbic acid. Indian J Exp Biol (2000); 38: 604- 606.

16. Masuda Y, Kikuzaki H, Hisamoto M, and Nakatani N. Antioxidant properties of gingerol related compounds from ginger. Biofactors (2004); 21: 293- 296.

17. Ahmed RS, Suke SG, Seth V, Chakraborti A, Tripathi AK, and Banerjee BD. Protective effects of dietary ginger (Zingiber officinales Rosc.) on lindane-induced oxidative stress in rats. Phytother Res (2008); 22: 902 -906.

18. Shukla Y, and Singh M. Cancer preventive properties of ginger: a brief review. Food Chem Toxicol (2007); 45: 683 -690.

19. Habib SH, Makpol S, bdul Hamid NA, Das S, Ngah WZ, and Yusof YA. Ginger extract (Zingiber officinale) has anti-cancer and anti-inflammatory effects on ethionine-induced hepatoma rats. Clinics (Sao Paulo) (2008); 63: 807- 813.

20. Thomson M, Al-Qattan KK, Al-Sawan SM, Alnaqeeb MA, Khan I, and Ali M. The use of ginger (Zingiber officinale Rosc.) as a potential anti-inflammatory and antithrombotic agent. Prostaglandins Leukot Essent Fatty Acids (2002); 67: 475- 478 .

21. Fuhrman B, Rosenblat M, Hayek T, Coleman $\mathrm{R}$, and Aviram M. Ginger extract consumption reduces plasma cholesterol, inhibits LDL oxidation and attenuates development of atherosclerosis in atherosclerotic, apolipoprotein E-deficient mice. J Nutr (2000); 130: 1124- 1131.
22. Bhandari U, Kanojia R, and Pillai KK. Effect of ethanolic extract of Zingiber officinale on dyslipidaemia in diabetic rats. J Ethnopharmacol (2005); 97: 227 -230.

23. Dollery C, Boobis A, Rawilins M, Thomas S and Wilkins M: Simvastatin In: Dollery C, Boobis A, Rawilins M, Thomas S and Wilkins M, editors. Therapeutic drugs. $2^{\text {nd }}$ ed: Churchill Livingstone (1999): S37-S42.

24. Syed N, Arshad S, Syed A, Ahmad M, Khan F and Ahmad B. A comparative study of antioxidant vitamins and simvastatin in hypercholestremic rabbits. Pak. J. Pharm. Sci (2011); 24(4): 479- 484

25. Iranloye BO, Arikawe AP, Rotimi G and Sogbade AO. Anti diabetic and antioxidant effects of Zingiber Officinale on alloxan induced and insulin resistant diabetic male rats. Nig. J. Physiol. Sci (2011); 26: 089 -096

26. Bancroft JD and Gamblo. Theory and practice of histological techniques $5^{\text {th }}$ edition, Churchill Livingston, London, New York, Philadelphia, Toronto (2002).

27. Hayat, M.A. Principles and techniques of electron microscopy: Biological applications $4^{\text {th }}$ edition, Cambridge, UK: Cambridge University Press (2002).

28. Koracevic D, Koracevic G, Djordjevic V, Andrejevic S, and Cosic V. Method for the measurement of antioxidant activity in human fluids. J Clin Pathol (2001); 54: 356- 361.

29. Harma M, Harma M, and Erel O. Measurement of the total antioxidant response in preeclampsia with a novel automated method. Eur J Obstet Gynecol Reprod Biol (2005); 118: 47 -51.

30. Sirvent P, Bordenave S, Vermaelen M, Roels B, Vassort G, Mercier J, Raynaud E, and Lacampagne A. Simvastatin induces impairment in skeletal muscle while heart is protected. BiochemBiophys Res Commun 2005; 338: 1426- 1434.

31. Sirvent P, Mercier J, Vassort G, and Lacampagne A. Simvastatin triggers mitochondria-induced $\mathrm{Ca} 2+$ signaling alteration in skeletal muscle. Biochem Biophys Res Commun 2005; 329: 1067- 1075.

32. Baker SK. Molecular clues into the pathogenesis of statin-mediated muscle toxicity. Muscle Nerve 2005; 31: $572-580$. 
33. Huynh T, Cordato D, Yang F, Choy T, Johnstone $\mathrm{K}$, Bagnall F, Hitchens N, and Dunn R. HMG CoA reductase-inhibitor-related myopathy and the influence of drug interactions. Intern Med J 2002; 32: 486- 490 .

34. Abdel-Hamid KM, Shehata MM, and Fares S.F. A light microscopic study on the effects of simvastatin (a hypolipidemic drug) on skeletal muscle fibers and liver of adult and aged male albino rats. Assiut Faculty of Medicine $24^{\text {th }}$ Annual Conference 2006: 19- 35.

35. Hassan NF, El- Bakry NA, Shalaby NM, Ghobara MM, and Bayomi NA. Histological Study of the Effect of Simvastatin on the Skeletal Muscle Fibers in Albino Rat and the Possible Protective Effect of Coenzyme Q 10. Egypt J Histol 2009; 31: $216-226$.

36. Scherz-Shouval R, Shvets E, Fass E, Shorer H, Gil L, and Elazar Z. Reactive oxygen species are essential for autophagy and specifically regulate the activity of Atg4. EMBO J 2007; 26: 1749- 1760 .

37. Gomes LC, and Scorrano L. Mitochondrial morphology in mitophagy and macroautophagy. Biochim Biophys Acta 2013; 1833: 205 -212.

38. Wakabayashi T. Megamitochondria formation physiology and pathology. J Cell Mol Med 2002; 6: 497- 538.

39. Hassan M, Feyen O, and Grinstein E. Fasinduced apoptosis of renal cell carcinoma is mediated by apoptosis signal-regulating kinase 1 via mitochondrial damage-dependent caspase- 8 activation. Cell Oncol 2009; 31: 437- 456.

40. Kucharczyk R, Zick M, Bietenhader M, Rak M, Couplan E, Blondel M, Caubet SD, and di Rago JP. Mitochondrial ATP synthase disorders: molecular mechanisms and the quest for curative therapeutic approaches. Biochim Biophys Acta 2009; 1793: 186- 199.

41. Khan NA, Auranen M, Paetau I, Pirinen E, Euro L, Forsstrom S, Pasila L, Velagapudi V, Carroll CJ, Auwerx J, and Suomalainen A. Effective treatment of mitochondrial myopathy by nicotinamideriboside, a vitamin B3. EMBO Mol Med 2014; 6: 721- 731.

42. Shoubridge EA. (1994): Mitochondrial DNA diseases: histological and cellular studies. J Bioenerg. Biomembr. 26(3):301 -310.
43. Melov S, Schneider JA, Coskun PE, Bennett DA and Wallace DC . (1999): Mitochondrial DNA rearrangements in aging human brain and in situ PCR of mtDNA. Neurobiol. Aging ; 20(5): $565-571$.

44. Vladutiu GD, Simmons Z, Isackson PJ, Tarnopolsky M, Peltier WL, Barboi AC, Sripathi N, Wortmann RL and Phillips PS . (2006): Genetic risk factors associated with lipid-lowering druginduced myopathies. Muscle Nerve; 34(2): 153- 162.

45. Burton $\mathrm{GW}$, and Ingold $\mathrm{KU}$. Vitamin $\mathrm{E}$ as an in vitro and in vivo antioxidant. Ann N Y Acad Sci 1989; 570: $7-22$.

46. Urano S, Matsuo M, Sakanaka T, Uemura I, Koyama M, Kumadaki I, Fukuzawa K. Mobility and molecular orientation of vitamin $\mathrm{E}$ in liposomal membranes as determined by 19F NMR and fluorescence polarization techniques. Arch Biochem Biophys 1993; 303: 10- 14.

47. Erin AN, Spirin MM, Tabidze LV, and Kagan VE. Formation of alpha-tocopherol complexes with fatty acids. A hypothetical mechanism of stabilization of biomembranes by vitamin E. Biochim Biophys Acta 1984; 774: 96 -102.

48. Sen CK, Khanna S, and Roy S. Tocotrienols: Vitamin E beyond tocopherols. Life Sci 2006; 78: $2088-2098$.

49. Sinzinger H, and O'Grady J. Professional athletes suffering from familial hypercholesterolaemia rarely tolerate statin treatment because of muscular problems. Br J Clin Pharmacol 2004; 57: 525- 528.

50. Ippoushi $\mathrm{K}$, Azuma $\mathrm{K}$, Ito $\mathrm{H}$, Horie $\mathrm{H}$, and Higashio H. [6]-Gingerol inhibits nitric oxide synthesis in activated J774.1 mouse macrophages and prevents peroxynitrite-induced oxidation and nitration reactions. Life Sci 2003; 73: 3427- 3437.

51. Tjendraputra E, Tran VH, Liu-Brennan D, Roufogalis BD, and Duke CC. Effect of ginger constituents and synthetic analogues on cyclooxygenase- 2 enzyme in intact cells. Bio org Chem 2001; 29: 156- 163.

52. Tripathi S, Maier KG, Bruch D, and Kittur DS. Effect of 6-gingerol on pro-inflammatory cytokine production and costimulatory molecule expression in murine peritoneal macrophages. J Surg Res 2007; 138: 209 -213.

53. Mashhadi NS, Ghiasvand R, Askari G, Hariri M, 
Darvishi L, and Mofid MR. Anti-oxidative and anti-inflammatory effects of ginger in health and physical activity: review of current evidence. Int J Prev Med 2013; 4: S36-S42.

54. Roufogalis BD. Zingiber officinale (Ginger): A Future Outlook on Its Potential in Prevention and Treatment of Diabetes and Prediabetic States. New Journal of Science 2014; 2014: 1- 15.

55. Kahn BB, Alquier T, Carling D, and Hardie DG. AMP-activated protein kinase: ancient energy gauge provides clues to modern understanding of metabolism. Cell Metab 2005; 1: 15 -25.

56. Galtier F, Mura T, Raynaud de ME, Chevassus H, Farret A, Gagnol JP, Costa F, Dupuy A, Petit P, Cristol JP, Mercier J, and Lacampagne A. Effect of a high dose of simvastatin on muscle mitochondrial metabolism and calcium signaling in healthy volunteers. Toxicol Appl Pharmacol 2012; 263: $281-286$.

57. Heeba GH, and Abd-Elghany MI. Effect of combined administration of ginger (Zingiber officinale Roscoe) and atorvastatin on the liver of rats. Phytomedicine 2010; 17: $1076-1081$.

58. Owczarek J, Jasinska M, and Orszulak-Michalak D. Drug-induced myopathies. An overview of the possible mechanisms. Pharmacol Rep 2005; 57: $23-34$.

59. Simsek ON, Bal IB, Sara Y, Onur R, and Severcan F. Structural and functional characterization of simvastatin-induced myotoxicity in different skeletal muscles. Biochim Biophys Acta 2014; 1840: $406-415$.

60. Chang WS, Chang YH, Lu FJ, and Chiang HC. Inhibitory effects of phenolics on xanthine oxidase. Anticancer Res 1994; 14: 501- 506. 


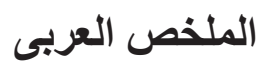

\section{الدور الوقائى المحتمل لخلاصة الزنجبيل مقابل فيتامين( هـ ) ضد اعتلال العضلات الهيكلية الناتج

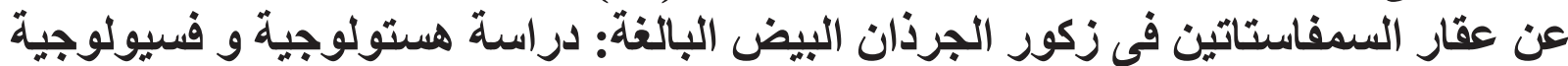 و كيمياء حيوية}

\section{كوثر محمد عبد الحميد1 ، أسماء فتحى عبد المولى1 ، فاطمة ياسين عبد المتجلى مليجى1 1 وإيمان سيا حسن عند عبد الله}

\section{قسم الهستولوجيا، 2قسم الفيسيولوجيا، كلية الطب، جامعة أسيوط}

المقدمة: تستخدم مجمو عة عقاقير الاستاتينز فى خفض نسبة البروتينات الدهنية منخفضة الكثافة الضارة و نسبة الكوليسترول

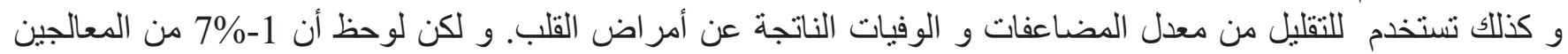

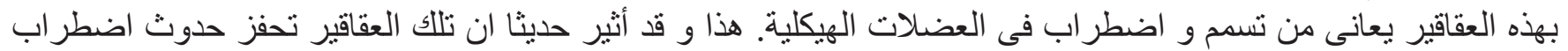

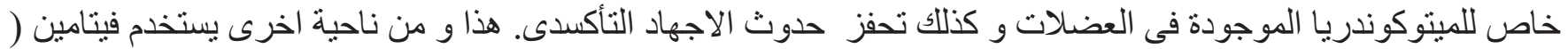

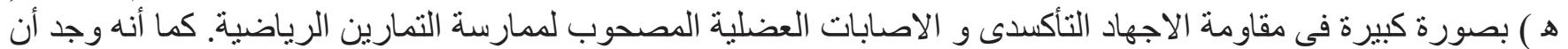
مستخلص الزنجبيل ذو قيمة فئمان عالية كمضاد للأكسدة. الههف من البحث:: تقصى الدور الوقائى المحتمل للزنجبيل مقابل فيتامين ( هـ ) ضد اضطر التهابات العضلات الهيكلية الناتج عن

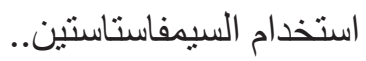

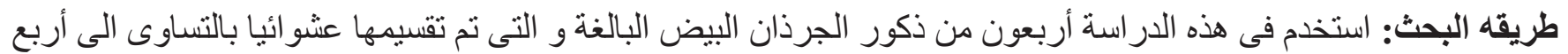

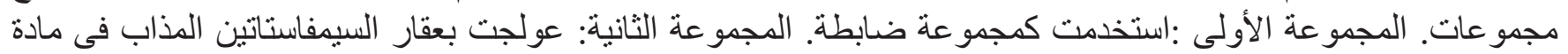

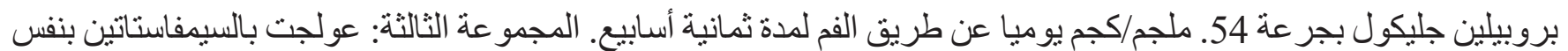

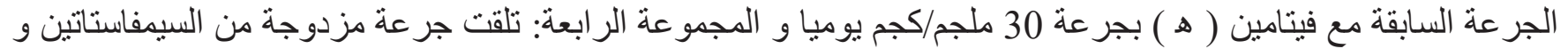

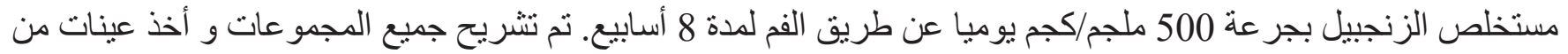

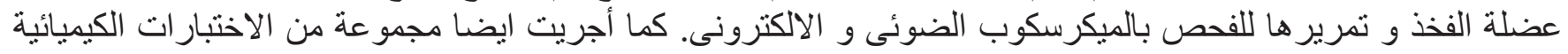
و عمل تحليل احصائى لها.

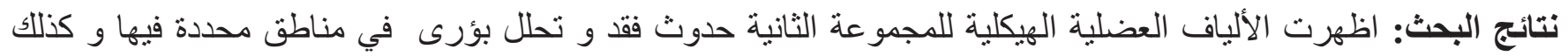

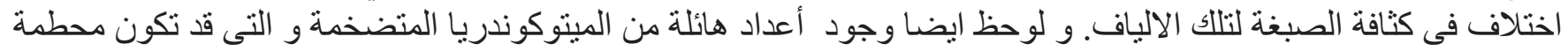

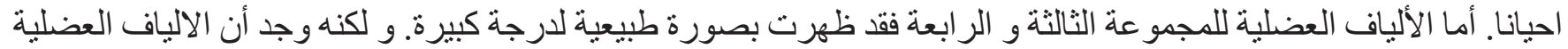

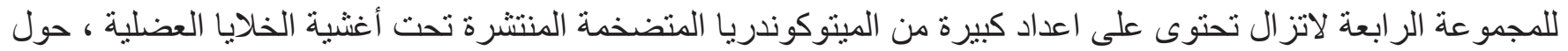

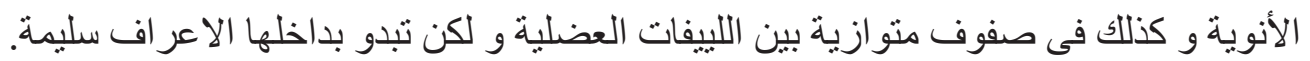

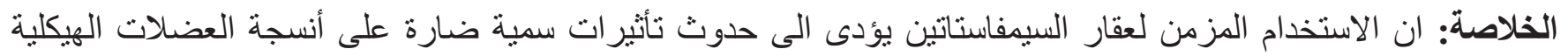

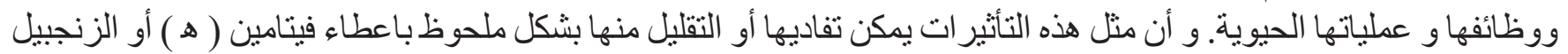
مصاحبا للسيمفاستاتين. 